\title{
Conformationally-Gated Electron Transfer in Iso-1-Cytochrome c: Engineering the Rate of a Conformational Switch
}

Saritha Baddam and Bruce E. Bowler*

Department of Chemistry and Biochemistry, University of Denver, 2190 East Iliff Avenue, Denver, Colorado 80208.

\section{Supporting Information}

\section{Anaerobic electron transfer kinetic experiments using stopped-flow methods}

WT and H73 iso-1-cytochrome $c$ were isolated from Saccharomyces cerevisiae as previously described (ref. 2, manuscript). Horse heart cytochrome $c$ was from Sigma. Commercial $\left[\mathrm{Ru}\left(\mathrm{NH}_{3}\right)_{6}\right] \mathrm{Cl}_{3}$ (Strem Chemicals) was reduced with zinc by the method of Fergusson and Love. ${ }^{\mathrm{S} 1}$ The $\left[\mathrm{Ru}\left(\mathrm{NH}_{3}\right)_{6}\right] \mathrm{Cl}_{2}$ was dried in a vacuum dessicator which was then refilled with argon. The product was stored at $-20{ }^{\circ} \mathrm{C}$ and care was taken to minimize exposure of $\left[\mathrm{Ru}\left(\mathrm{NH}_{3}\right)_{6}\right] \mathrm{Cl}_{2}$ to air and moisture to prevent oxidation. IR spectroscopy was used to confirm the product $\left(1217 \mathrm{~cm}^{-1}\right.$ band characteristic of $\mathrm{Ru}(\mathrm{II})$ complex). ${ }^{\mathrm{S} 2}$

The stopped-flow experiments were done using an Applied Photophysics $\pi^{*}-180$ spectropolarimeter with a stopped-flow unit operating in kinetics mode. The day before the experiments were done, the flow cell and the drive syringes were soaked overnight in $50 \mu \mathrm{M}$ riboflavin, reduced with $1 \mathrm{mM}$ EDTA and light, to ensure anaerobic conditions. ${ }^{\mathrm{S} 3}$ Prior to the experiments, the buffer used for the experiments was degassed with at least 3 cycles of evacuation and refilling with argon gas (high purity grade, $99.99 \%$ ). A dual manifold was used for this purpose, which consisted of two lines, one for vacuum and the other for argon gas. Argon gas was first passed through an oxy-trap column (Alltech) to ensure the removal of any residual $\mathrm{O}_{2}$. An oxy-trap indicator (Alltech) was also used, which changes color if there is oxygen in the line.

In the case of horse heart cytochrome $c, 0.1 \mathrm{M}$ sodium phosphate buffer, $\mathrm{pH} 7.0$ was used, to be consistent with previous literature (ref 13, manuscript). In the case of the yeast proteins, the experiments were done with the following buffers: $10 \mathrm{mM}$ Tris buffer in $0.1 \mathrm{M}$ $\mathrm{NaCl}, \mathrm{pH} 7.5 ; 10 \mathrm{mM}$ MES in $0.1 \mathrm{M} \mathrm{NaCl}, \mathrm{pH} 6.0$ and 6.5. Before starting the experiments, the riboflavin was driven out of the flow cell and syringes, and the appropriate degassed buffer was used to wash out the remaining riboflavin. Then, a baseline at $550 \mathrm{~nm}$ was run. The rate of $\mathrm{Fe}^{\mathrm{III}}$ reduction was monitored at $550 \mathrm{~nm}$, the wavelength of maximum change in the absorbance for the conversion between oxidized and reduced forms of cytochrome $c$.

All proteins were oxidized with $\mathrm{K}_{3}\left[\mathrm{Fe}(\mathrm{CN})_{6}\right]$ prior to kinetic experiments then separated from the $\mathrm{K}_{3}\left[\mathrm{Fe}(\mathrm{CN})_{6}\right]$ by $\mathrm{G}-25$ chromatography. The protein was diluted with the appropriate degassed buffer to obtain $10 \mu \mathrm{M}$ protein concentration. The protein solution was degassed and refilled with argon at least 3 times. Once the protein solution was degassed, the Ru(II) solution was made. The reduction of cytochrome $c$ was done using $\mathrm{Ru}(\mathrm{II})$ at three different concentrations, $2.5 \mathrm{mM}, 5 \mathrm{mM}$ and $10 \mathrm{mM}$ (2x concentrations). So, all bimolecular kinetics data are pseudo first order. Each solution was made by weighing out $\mathrm{Ru}(\mathrm{II})$ fresh each time to ensure the reducing nature of the reagent. $\mathrm{Ru}(\mathrm{II})$ is unstable if kept in solution for a long time and decomposes into $\mathrm{Ru}(\mathrm{III})$ and metal. ${ }^{\mathrm{S} 4}$ To make $2.5 \mathrm{mM} \mathrm{Ru}(\mathrm{II}), 10 \mathrm{~mL}$ of degassed buffer was taken in a $25 \mathrm{~mL}$ Erlenmeyer flask or a round-bottomed flask, closed with a rubber septum and then degassed at least 3 times as mentioned above. Then, $6.85 \mathrm{mg}$ of $\left[\mathrm{Ru}\left(\mathrm{NH}_{3}\right)_{6}\right] \mathrm{Cl}_{2}$ was weighed into another $25 \mathrm{~mL}$ Erlenmeyer flask, closed with a rubber septum and the flask wrapped with 
aluminum foil. The flask with the solid $\left[\mathrm{Ru}\left(\mathrm{NH}_{3}\right)_{6}\right] \mathrm{Cl}_{2}$ was quickly degassed, refilled with argon, and then the buffer from the other flask was cannula transferred into it. The flask with the buffer was kept under argon pressure and the flask with $\left[\mathrm{Ru}\left(\mathrm{NH}_{3}\right)_{6}\right] \mathrm{Cl}_{2}$ under vacuum, to aid in the flow during cannula transfer. Once the buffer was transferred, the solution was shaken to dissolve the ruthenium compound and then the solution was degassed as described above. This step was done as rapidly as possible to prevent oxidation of the ruthenium compound. Then, the degassed $\mathrm{Ru}(\mathrm{II})$ and the protein solutions were immediately taken to the stopped-flow instrument using gas tight syringes. The solutions were injected into the drive syringes and the reduction monitored. After mixing, the protein was at $5 \mu \mathrm{M}$ and the $\mathrm{Ru}(\mathrm{II})$ at $1.25 \mathrm{mM}$ final concentrations in the appropriate buffer. Similarly, $5 \mathrm{mM}$ and $10 \mathrm{mM} \mathrm{Ru(II)} \mathrm{solutions} \mathrm{were} \mathrm{also} \mathrm{made} \mathrm{using}$ appropriate amounts of $\left[\mathrm{Ru}\left(\mathrm{NH}_{3}\right)_{6}\right] \mathrm{Cl}_{2}$ in appropriate amounts of buffer. The final concentrations after mixing for these solutions were $2.5 \mathrm{mM}$ and $5 \mathrm{mM}$ respectively. At each concentration of $\mathrm{Ru}(\mathrm{II})$, a minimum of four trials were done and a total of 1000 points were collected over 2 seconds on a logarithmic time scale. Data were also collected on a longer time scale ( $\sim 50-100 \mathrm{~s})$ with 5000 data points also on a logarithmic time scale. The dead time for stopped-flow mixing was measured using acorbate reduction of 1,6-dichlorophenolindophenol, ${ }^{\mathrm{S} 5}$ and was found to be $1.0 \mathrm{~ms}$ under our mixing conditions. The data were corrected for the dead time of the experiment.

Analysis of the data were done using the curve fitting program, SigmaPlot (v. 7.0). The data were fit to single (eq S1), double (eq S2) or triple (eq S3) exponential rise to maximum equations depending on the type of protein and the time scale.

Eq. S1

$$
\mathrm{A}_{550}(\mathrm{t})=\mathrm{A}_{550}(0)+\mathrm{a}(1-\exp (-\mathrm{kt}))
$$

Eq. S2 $\quad \mathrm{A}_{550}(\mathrm{t})=\mathrm{A}_{550}(0)+\mathrm{a}_{1}\left(1-\exp \left(-\mathrm{k}_{1} \mathrm{t}\right)\right)+\mathrm{a}_{2}\left(1-\exp \left(-\mathrm{k}_{2} \mathrm{t}\right)\right)$

Eq. S3 $\quad A_{550}(t)=A_{550}(0)+a_{1}\left(1-\exp \left(-k_{1} t\right)\right)+a_{2}\left(1-\exp \left(-k_{2} t\right)\right)+a_{3}\left(1-\exp \left(-k_{3} t\right)\right)$

where $\mathrm{A}_{550}(\mathrm{t})$ is the absorbance as a function of time at $550 \mathrm{~nm}, \mathrm{~A}_{550}(0)$ is the absorbance at 550 $\mathrm{nm}$ at time zero, $\mathrm{a}_{1}, \mathrm{a}_{2}$ and $\mathrm{a}_{3}$ are amplitudes and $\mathrm{k}_{1}, \mathrm{k}_{2}$ and $\mathrm{k}_{3}$ are rate constants. The observed rate constants for ET obtained from equations S1, S2, and S3 were the fit to linear equation S4.

Eq. S4 $\quad \mathrm{k}_{\mathrm{obs}}=\mathrm{k}_{\mathrm{ET}} *[\mathrm{Ru}]$

where $\mathrm{k}_{\mathrm{obs}}$ is the observed rate constant, $\mathrm{k}_{\mathrm{ET}}$ is the bimolecular electron transfer rate constant and $[\mathrm{Ru}]$ is the concentration of the reducing agent.

\section{References}

S1. Fergusson, J. E.; Love, J. L. Inorg. Syn. 1972, 13, 208-213.

S2. Allen, A. D.; Senoff, C. V. Can. J. Chem. 1966, 45, 1337-1341.

S3. Ramsey, R. R.; Koerber, S. C.; Singer, T. P. Biochemistry, 1987, 26, 3045-3050.

S4. Lever, F. M.; Powell, A. R. J. Chem. Soc. A, 1969, 1477-1482.

S5. Tonomura, B.; Nakatani, H.; Ohnishi, M.; Yamaguchi-Ito, J.; Hiromi, K. Anal. Biochem. 1978, 84, 370-383. 


\section{Tables of Rate Constants}

\section{H73 iso-1-cytochrome $c$ :}

Table S1. Bimolecular rate constant, $\mathrm{k}_{\mathrm{ET}}$, for reduction of $\mathrm{H} 73$ iso-1-cytochrome $c$ by $\mathrm{a}_{6} \mathrm{Ru}^{2+}$ at different $\mathrm{pH}$ values. ${ }^{a}$

\begin{tabular}{cc}
\hline $\mathrm{pH}$ & $\mathrm{k}_{\mathrm{ET}}, \mathrm{M}^{-1} \mathrm{~s}^{-1}$ \\
\hline 6.0 & $3.6 \pm 0.3 \times 10^{4}$ \\
6.5 & $3.6 \pm 0.1 \times 10^{4}$ \\
7.5 & $4.4 \pm 0.1 \times 10^{4}$ \\
\hline
\end{tabular}

\footnotetext{
${ }^{a}$ The $\mathrm{k}_{\mathrm{ET}}$ values are obtained by fitting the $\mathrm{k}_{\mathrm{obs}}$ for the fast phase from Table 1 in the manuscript to equation $\mathrm{S} 4$. The reported error in $\mathrm{k}_{\mathrm{ET}}$ is the error in the slope of Eq S4 obtained from the fit of the fast phase $\mathrm{k}_{\mathrm{obs}}$ data in Table 1 using SigmaPlot.
}

Table S2. Rate constants and amplitudes for the slowest phase of reduction of $\mathrm{H} 73$ iso-1-cytochrome $c$ by $\mathrm{a}_{6} \mathrm{Ru}^{2+}$ derived from data acquired on a $100 \mathrm{~s}$ time scale. ${ }^{a}$

\begin{tabular}{cccc}
\hline $\mathrm{pH}$ & {$\left[\mathrm{a}_{6} \mathrm{Ru}^{2+}\right], \mathrm{mM}$} & $\mathrm{k}_{\text {obs }}, \mathrm{s}^{-1}$ & amplitude, a.u. \\
\hline 6.0 & 1.25 & $0.057 \pm 0.003$ & $0.0050 \pm 0.0001$ \\
& 2.5 & $0.059 \pm 0.009$ & $0.0043 \pm 0.0003$ \\
6.5 & 5.0 & $0.055 \pm 0.003$ & $0.0042 \pm 0.0006$ \\
& 1.25 & $0.062 \pm 0.008$ & $0.0094 \pm 0.0004$ \\
7.5 & 2.5 & $0.0667 \pm 0.0001$ & $0.0093 \pm 0.0001$ \\
& 5.0 & $0.0614 \pm 0.0002$ & $0.0099 \pm 0.0001$ \\
& $1.25^{b}$ & $0.072 \pm 0.001$ & $0.0144 \pm 0.0001$ \\
& 2.5 & $0.066 \pm 0.001$ & $0.0143 \pm 0.0002$ \\
& 5.0 & $0.056 \pm 0.001$ & $0.0142 \pm 0.0002$ \\
\hline
\end{tabular}

${ }^{a}$ Buffers were $10 \mathrm{mM}$ with $100 \mathrm{mM} \mathrm{NaCl}$ (pH 6 and 6.5, MES, pH 7.5, Tris). All data acquired at $25 \pm 0.1{ }^{\circ} \mathrm{C}$. The reported errors are the standard deviation about the average of at least four trials. ${ }^{b} \mathrm{At} \mathrm{pH} \mathrm{7.5,} \mathrm{only} \mathrm{one} \mathrm{trial} \mathrm{was} \mathrm{taken} \mathrm{at} 1.25 \mathrm{mM} \mathrm{a}_{6} \mathrm{Ru}^{2+}$ concentration, so the reported errors are the standard error of the parameters in the fit carried out with SigmaPlot. 


\section{WT iso-1-cytochrome $c$ :}

Table S3. Rate constants and amplitudes for the reduction of WT iso-1-cytochrome $c$ by $\mathrm{a}_{6} \mathrm{Ru}^{2+}$ as a function of $\mathrm{pH}^{a}$

\begin{tabular}{cccc}
\hline $\mathrm{pH}$ & {$\left[\mathrm{a}_{6} \mathrm{Ru}^{2+}\right], \mathrm{mM}$} & $\mathrm{k}_{\text {obs }}, \mathrm{s}^{-1}$ & amplitude, a.u. \\
\hline 6 & 1.25 & $55 \pm 1$ & $0.108 \pm 0.001$ \\
& 2.5 & $101 \pm 2$ & $0.108 \pm 0.001$ \\
6.5 & 5.0 & $220 \pm 2$ & $0.112 \pm 0.001$ \\
& 1.25 & $47.2 \pm 0.1$ & $0.104 \pm 0.001$ \\
& 2.5 & $83.4 \pm 0.4$ & $0.104 \pm 0.002$ \\
7 & 5.0 & $238 \pm 3$ & $0.108 \pm 0.004$ \\
& 1.25 & $55.4 \pm 0.5$ & $0.098 \pm 0.001$ \\
7.5 & 2.5 & $123 \pm 2$ & $0.101 \pm 0.001$ \\
& 5.0 & $397 \pm 12$ & $0.116 \pm 0.004$ \\
& 1.25 & $38.9 \pm 0.5$ & $0.093 \pm 0.001$ \\
& 2.5 & $76.5 \pm 0.7$ & $0.094 \pm 0.001$ \\
& 5.0 & $208 \pm 5$ & $0.096 \pm 0.002$ \\
\hline
\end{tabular}

${ }^{a}$ Buffers were $10 \mathrm{mM}$ with $100 \mathrm{mM} \mathrm{NaCl}$ (pH 6 and 6.5, MES, pH 7.5, Tris) except for $\mathrm{pH} 7$, which was $100 \mathrm{mM}$ sodium phosphate. All data acquired at $25 \pm 0.1{ }^{\circ} \mathrm{C}$. The reported errors are the standard deviation about the average of at least four trials.

Table S4. Bimolecular rate constant, $\mathrm{k}_{\mathrm{ET}}$, for reduction of WT iso-1-cytochrome $c$ by $\mathrm{a}_{6} \mathrm{Ru}^{2+}$ at different $\mathrm{pH}$ values. ${ }^{a}$

\begin{tabular}{cc}
\hline $\mathrm{pH}$ & $\mathrm{k}_{\mathrm{ET}}, \mathrm{M}^{-1} \mathrm{~s}^{-1}$ \\
\hline 6.0 & $4.5 \pm 0.3 \times 10^{4}$ \\
6.5 & $5.3 \pm 0.8 \times 10^{4}$ \\
$7.0^{b}$ & $9.4 \pm 1.4 \times 10^{4}$ \\
7.5 & $4.6 \pm 0.6 \times 10^{4}$ \\
\hline
\end{tabular}

${ }^{a}$ The $\mathrm{k}_{\mathrm{ET}}$ values are obtained by fitting the $\mathrm{k}_{\text {obs }}$ data from Table S3 to equation S4.

${ }^{b}$ The $\mathrm{pH} 7.0$ data was obtained in $100 \mathrm{mM}$ sodium phosphate. 
At $\mathrm{pH} 7.5$, a small amount of a very slow $\mathrm{a}_{6} \mathrm{Ru}^{2+}$-induced reduction phase could be observed for WT iso-1-cytochrome $c$ (Table S5). This very slow phase was not detectable at $\mathrm{pH}$ 6.0 or 6.5 . $\mathrm{pH} 7.5$ is 1.1 units below the midpoint $\mathrm{pH}$ for the alkaline conformational transition of WT iso-1-cytochrome $c$ (refs. $2 \mathrm{c}$ and 5a, manuscript), so somewhat less than $10 \%$ of the protein should be in the alkaline form at $\mathrm{pH}$ 7.5. This phase appears to by independent of $\left[\mathrm{a}_{6} \mathrm{Ru}^{2+}\right]$, so it can be assigned to electron transfer gated by the conformational change from the alkaline to the native state of the protein (ref. 1, manuscript).

Table S5. Rate constants and amplitudes for the slowest phase for reduction of WT iso-1-cytochrome $c$ by $\mathrm{a}_{6} \mathrm{Ru}^{2+}$ at $\mathrm{pH} 7.5$ and $25 \pm 0.1$ ${ }^{\circ} \mathrm{C}$ from data acquired on a $100 \mathrm{~s}$ time scale.

\begin{tabular}{ccc}
\hline$\left[\mathrm{a}_{6} \mathrm{Ru}^{2+}\right], \mathrm{mM}$ & $\mathrm{k}_{\mathrm{obs}}, \mathrm{s}^{-1}$ & amplitude, a.u. \\
\hline 1.25 & $0.034 \pm 0.006$ & $0.0052 \pm 0.0003$ \\
2.5 & $0.0353 \pm 0.0004$ & $0.0048 \pm 0.0006$ \\
5.0 & $0.0041 \pm 0.006$ & $0.0046 \pm 0.0004$ \\
\hline
\end{tabular}

